\title{
Front Matter: Volume 10018
}

, "Front Matter: Volume 10018," Proc. SPIE 10018, Advanced Laser Processing and Manufacturing, 1001801 (30 December 2016); doi: $10.1117 / 12.2267261$

SPIE. Event: SPIE/COS Photonics Asia, 2016, Beijing, China 


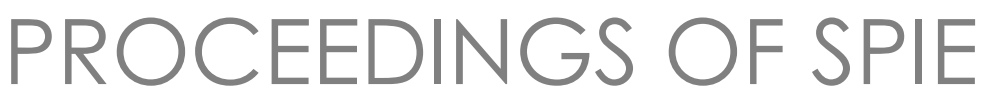

\title{
Advanced Laser Processing and Manufacturing
}

\author{
Minlin Zhong \\ Jonathan Lawrence \\ Minghui Hong \\ Jian Liu \\ Editors
}

13 October 2016

Beijing, China

\author{
Sponsored by \\ SPIE \\ COS-Chinese Optical Society
}

\section{Cooperating Organizations}

Tsinghua University (China) • Peking University (China) • University of Science and Technology of China (China) • Zhejiang University (China) • Tianjin University (China) • Beijing Institute of Technology (China) • Beijing University of Posts and Telecommunications (China) - Nankai University (China) - Changchun University of Science and Technology (China) • University of Shanghai for Science and Technology (China) • Capital Normal University (China) - Huazhong University of Science and Technology (China) • Beijing Jiaotong University (China) • Shanghai Institute of Optics and Fine Mechanics (China) - Changchun Institute of Optics and Fine Mechanics (China) - Institute of Semiconductors (China) • Institute of Optics and Electronics (China) • Institute of Physics (China) • Shanghai Institute of Technical Physics (China) - China Instrument and Control Society (China) - Optoelectronics Technology Committee, COS (China) • SPIE National Committee in China (China) • Optical Society of Japan (Japan) • Optical Society of Korea (Korea, Republic of) - The Australian Optical Society (Australia) - Optics and Photonics Society of Singapore (Singapore) • European Optical Society

Supporting Organizations

CAST-China Association for Science and Technology (China)

NSFC-National Nature Science Foundation (China)

Published by

SPIE

\section{Volume 10018}


The papers in this volume were part of the technical conference cited on the cover and title page. Papers were selected and subject to review by the editors and conference program committee. Some conference presentations may not be available for publication. Additional papers and presentation recordings may be available online in the SPIE Digital Library at SPIEDigitallibrary.org.

The papers reflect the work and thoughts of the authors and are published herein as submitted. The publisher is not responsible for the validity of the information or for any outcomes resulting from reliance thereon.

Please use the following format to cite material from these proceedings:

Author(s), "Title of Paper," in Advanced Laser Processing and Manufacturing, edited by Minlin Zhong, Jonathan Lawrence, Minghui Hong, Jian Liu, Proceedings of SPIE Vol. 10018 (SPIE, Bellingham, WA, 2016) Seven-digit Article CID Number.

ISSN: 0277-786X

ISSN: 1996-756X (electronic)

ISBN: 9781510604551

ISBN: 9781510604568 (electronic)

Published by

SPIE

P.O. Box 10, Bellingham, Washington 98227-0010 USA

Telephone +1 3606763290 (Pacific Time) · Fax +1 3606471445

SPIE.org

Copyright (C) 2016, Society of Photo-Optical Instrumentation Engineers.

Copying of material in this book for internal or personal use, or for the internal or personal use of specific clients, beyond the fair use provisions granted by the U.S. Copyright Law is authorized by SPIE subject to payment of copying fees. The Transactional Reporting Service base fee for this volume is $\$ 18.00$ per article (or portion thereof), which should be paid directly to the Copyright Clearance Center (CCC), 222 Rosewood Drive, Danvers, MA 01923. Payment may also be made electronically through CCC Online at copyright.com. Other copying for republication, resale, advertising or promotion, or any form of systematic or multiple reproduction of any material in this book is prohibited except with permission in writing from the publisher. The CCC fee code is 0277-786X/16/\$18.00.

Printed in the United States of America.

Publication of record for individual papers is online in the SPIE Digital Library.

\section{SPIE. DIGTAL}

Paper Numbering: Proceedings of SPIE follow an e-First publication model. A unique citation identifier (CID) number is assigned to each article at the time of publication. Utilization of CIDs allows articles to be fully citable as soon as they are published online, and connects the same identifier to all online and print versions of the publication. SPIE uses a seven-digit CID article numbering system structured as follows:

- The first five digits correspond to the SPIE volume number.

- The last two digits indicate publication order within the volume using a Base 36 numbering

system employing both numerals and letters. These two-number sets start with 00, 01, 02, 03, 04, 05, 06, 07, 08, 09, OA, OB ... 0Z, followed by 10-1Z, 20-2Z, etc. The CID Number appears on each page of the manuscript. 


\title{
Contents
}

\author{
$\checkmark \quad$ Authors \\ vii Symposium Committee \\ ix Conference Committee
}

\section{SESSION 1 ADVANCED LASER PROCESSING AND MANUFACTURING I}

1001804 Fabrication of 3D embedded hollow structures inside polymer dielectric PMMA with femtosecond laser (Invited Paper) [10018-3]

$1001805 \mathrm{~W} / \mathrm{Cu}$ joining strengthened by femtosecond laser induced micron-scale interface structure [10018-4]

SESSION 2 ADVANCED LASER PROCESSING AND MANUFACTURING II

1001809 High-resolution laser lithography based on vortex laser and composite layer [10018-9]

$100180 \mathrm{~A}$ A blu-ray laser diode based dual-beam interference lithography for fabrication of diffraction gratings for surface encoders [10018-10]

\section{SESSION $3 \quad$ ADVANCED LASER PROCESSING AND MANUFACTURING III}

10018 OC Synthesis of nanoparticles by pulsed laser ablation in air: a versatile means for flexible synthesis and separation (Invited Paper) [10018-12]

10018 OD Energy-based approach as an example for a process signature for laser microprocessing [10018-6]

10018 OE In situ laser-induced synthesis of copper microstructures with high catalytic properties and sensory characteristics [10018-13]

$10018 \mathrm{OH}$ Optical methods for correction of surface acoustic wave sensors topology [10018-16]

10018 ol Switchable repetition rate bound solitons passively mode-locked fiber laser [10018-17]

10018 0J Research of the suppression of the phase noise in DFB fiber laser by self-injection locking [10018-18] 
Proc. of SPIE Vol. 10018 1001801-4

\section{Downloaded From: https://www.spiedigitallibrary.org/conference-proceedings-of-spie on 26 Apr 2023 Terms of Use: https://www.spiedigitallibrary.org/terms-of-use}




\section{Authors}

Numbers in the index correspond to the last two digits of the seven-digit citation identifier (CID) article numbering system used in Proceedings of SPIE. The first five digits reflect the volume number. Base 36 numbering is employed for the last two digits and indicates the order of articles within the volume. Numbers start with $00,01,02,03,04,05,06,07,08,09,0 A, 0 B . .0 Z$, followed by 10-1Z, 20-2Z, etc.

Chen, Tao, 04

Ermakov, Sergey S., OE

Fan, Peixun, 05

Gong, Dingwei, 05

Gordeychuk, Dmitry I., OE

$\mathrm{Hu}$, Anming, 04

Huang, T. T., OC

Jiang, Dafa, 05

Khairullina, Evgenia M., OE

Kochemirovsky, Vladimir A., $\mathrm{OE}$

Kukaev, Alexander, $\mathrm{OH}$

Li, Junwei, 04

Li, Xinghui, OA

Li, Xiongfeng, 09

Liang, Yiyong, 09

Lin, S. D., OC

Liu, Shibing, 04

Long, Jiangyou, 05

Lukyanov, Dmitry, $\mathrm{OH}$

Ma, Lina, OJ

Mehrafsun, Salar, OD

$\mathrm{Ni}$, Kai, OA

Panov, Maxim S., OE

Safronov, Daniil, $\mathrm{OH}$

Shevchenko, Sergey, $\mathrm{OH}$

Tang, Jianfeng, OJ

Tumkin, llya I., OE

Vollertsen, Frank, OD

Wang, Xiaohao, OA

Wang, Xuqin, 01

Xiong, Shuidong, OJ

Yao, Yong, Ol

Yu, Zhenglong, $0 \mathrm{~J}$

Zhan, Shichao, 09

Zhang, Hongjun, 05

Zhang, Yinfa, OJ

Zhao, Tong, OD

Zheng, Chong, 04

Zhong, Minlin, 05

Zhou, Qian, OA

Zhou, R., OC

Zhu, Xiangwen, OA 
Proc. of SPIE Vol. 10018 1001801-6

Downloaded From: https://www.spiedigitallibrary.org/conference-proceedings-of-spie on 26 Apr 2023 Terms of Use: https://www.spiedigitallibrary.org/terms-of-use 


\title{
Symposium Committees
}

\author{
General Chairs
}

Robert Lieberman, SPIE President, Lumoptix, LLC (United States)

Guangcan Guo, Chinese Optical Society President, University of Science and Technology of China (China)

General Co-chairs

Arthur Chiou, National Yang-Ming University (Taiwan, China)

Jianlin Cao, China Ministry of Science and Technology (China)

Junhao Chu, Shanghai Institute of Technical Physics (China)

Technical Program Chairs

Songlin Zhuang, University of Shanghai for Science and Technology

(China)

Xingde Li, Johns Hopkins University (United States)

Technical Program Co-chairs

Bingkun Zhou, Tsinghua University (China)

Qiming Wang, Institute of Semiconductors (China)

Tianchu Li, National Institute of Metrology (China)

Wei Huang, Nanjing University of Technology (China)

Ying Gu, PLA General Hospital (China)

Huilin Jiang, Changchun University of Science and Technology

(China)

Local Organizing Committee Chair

Qihuang Gong, Peking University (China) 
Local Organizing Committee Co-chairs

Xu Liu, Zhejiang University (China)

Daoyin Yu, Tianjin University (China)

Guoqiang Ni, Beijing Institute of Technology (China)

Shusen Xie, Fujian Normal University (China)

Xiaomin Ren, Beijing University of Posts and Telecommunications

(China)

General Secretary

Yan Li, Chinese Optical Society/Peking University (China)

Local Organizing Committee

Zhiping Zhou, Peking University (China)

Changhe Zhou, Shanghai Institute of Optics and Fine Mechanics, CAS

(China)

Qingming Luo, Huazhong University of Science and Technology

(China)

Chongxiu Yu, Beijing University of Posts and Telecommunication

(China)

Hongda Chen, Institute of Semiconductors (China)

Yongtian Wang, Beijing Institute of Technology (China)

Yiping Cui, Southeast University (China)

Xuping Zhang, Nanjing University (China)

Feijun Song, Daheng Corporation (China)

Cunlin Zhang, Capital Normal University (China)

Yanting Lu, Nanjing University (China)

Yuejin Zhao, Beijing Institute of Technology (China)

Chunqing Gao, Beijing Institute of Technology (China)

Tiegen Liu, Tianjin University (China)

Xiaocong Yuan, Nankai University (China)

Weimin Chen, Chongqing University (China)

Zhongwei Fan, Academy of Optoelectronics (China)

Hanyi Zhang, Tsinghua University (China)

Lan Wu, Zhejiang University (China)

Yongsheng Zhang, University of Science and Technology of China (China)

Hong Yang, Peking University (China)

Xiaoying Li, Tianjin University (China)

Wei Xiong, Chinese Optical Society (China) 


\section{Conference Committee}

Symposium Chairs

Robert A. Lieberman, Lumoptix, LLC (United States)

Wei Xiong, Chinese Optical Society (China)

Conference Chairs

Minlin Zhong, Tsinghua University (China)

Jonathan Lawrence, University of Chester (United Kingdom)

Minghui Hong, National University of Singapore (Singapore)

Jian Liu, PolarOnyx, Inc. (United States)

Conference Program Committee

Xue-Chun Lin, Institute of Semiconductors (China)

Rongshi Xiao, Beijing University of Technology (China)

Jianhua Yao, Zhejiang University of Technology (China)

Xiaoyan Zeng, Huazhong University of Science and Technology (China)

\section{Session Chairs}

1 Advanced Laser Processing and Manufacturing I

Peixun Fan, Tsinghua University (China)

2 Advanced Laser Processing and Manufacturing II

Ting Huang, Beijing University of Technology (China)

3 Advanced Laser Processing and Manufacturing III

Yingchun Guan, BeiHang University (China)

Rui Zhou, Xiamen University (China) 
Proc. of SPIE Vol. 10018 1001801-10

Downloaded From: https://www.spiedigitallibrary.org/conference-proceedings-of-spie on 26 Apr 2023 Terms of Use: https://www.spiedigitallibrary.org/terms-of-use 